\title{
Two Operations in Woods, 1866 and 1870
}

\section{Colonel Lonsdale Hale R.E.}

To cite this article: Colonel Lonsdale Hale R.E. (1897) Two Operations in Woods, 1866 and 1870, Royal United Services Institution. Journal, 41:233, 864-882, DOI: $\underline{10.1080 / 03071849709416046}$

To link to this article: http://dx.doi.org/10.1080/03071849709416046

\section{曲 Published online: 11 Sep 2009.}

Submit your article to this journal $\pi$

Щ Article views: 2

Q View related articles $\sqsubset$ 


\section{TWO OPERATIONS IN IVOODS, 1866 AND 1870. Compiled by Colonel LONSDALE HALE, late R.E. -}

OPERATIONS within woods form a tactical subject which much exercises the military mind. These operations are of two kinds, sometimes quite distinct from each other, sometimes combined. The one is the moving through the woods, the other is the fighting in the woods. The varieties of woods are so great that no rigid rule for the conduct of operations in them and applicable to all alike can be laid down. Woods vary in size, shape, and extent, and also in the character of the boundaries, which are in some cases clearly defined, whilst in others the wood shades away gradually into open country. The ground on which they stand varies in its topographical features as much as does ground outside them, hilly or flat, dry or swampy. The size, character, and distance apart of the trees, the presence or absence and the nature of the undergrowth vary not only in different woods, but in the same wood. Finally, as a rule, the characteristics of any particular wood are not known beforehand to the troops operating in it.. The principles which should govern tactical practice can be ascertained only by a careful cxamination and comparison of the tactical facts of actual war. As a contribution to. the records of these facts, is given in the following pages an account of the conduct of one and the same regiment operating in two woods precisely similar in character. The wording of the narratives. has closely followed that of the Regrimental History drawn up by Captain von Stuckrad.

The regiment is the German First Magdeburg Infantry Regiment No. 26. The scene of operations in the first instance is the Wood of Maslowed, or the Swip Wald, at Königgrätz, 3rd Ju ly, 1866 ; that of the second is the Bois de Givodeau, near Beaumont, 30th August, 1870. In the former, the operations included both moving through the wood and fighting in the wood; in the latter, the operation was that only of moving through the wood practically unopposed.

On both occasions the regiment consisted of three battalions, denominated 1st, 2nd, and Fusilier, and probably 900 strong. Each battalion was composed of four companies, numbered consecutively through the regiment from 1 to 12. Each company was divided into three zugs, of which one was designated the "schützen "zug (shooting or skirmishing zug). The operations in the Swip Wald will be the first 
described, but before dealing with them a few remarks on the constitution of the regiment seem desirable. As regards the men, the Regimental History does not give information as to the number of reservists called up to bring the regiment to war strength, but, probably, this number'was considerable.

When the Army was mobilised the regimental commander had been appointed to the command of an infantry brigade, and was succeeded by Lieut.-Colonel von Medem, from one of the regiments of the Guards. Major Paucke, the commander of the 1st Battalion, had been for nine years in the regiment; Major von Gilsa, the commander of the 2 nd Battalion, had been the whole of his service of twenty-seven years in the regiment, as also had Major von Schönholtz, of the Fusilier Battalion. As regards the twelve company leaders, the regiment was fortunate in having to send only one captain away on other duty; and one being retired, the places of these officers were taken by the two senior subalterns of the regiment. Further, of the twelve company leaders nearly all had been in the regiment from the time of entering the Service. With each company were besides four officers, or else individuals appointed as "doing officer's duty." These comprised seven regular ${ }^{1}$ first lieutenants, two first lieutenants from the Landwehr; sixteen regular second lieutenants, eight second lieutenants from the Landwehr, six Portepeefahnrich (a grade between cadet and officer); one regular vice-sergeant-major, and eight vice-eergeant-majors from the Landwehr, so that of the sixty company officers only thirty-five were its officers in peace-time. The regimental adjutant was a regular first lieutenant; the three battalion adjutants were regular second lieutenants.

The Fight in the Wood of Maslowed, July, 3rd, 1866. (Plan I.)

The 26th Regiment formed with the 66th Regiment the 13th Infantry Brigade, commanded by Major-General von Schwarzhoff; the 13th and the 14th Infantry Brigades constituted the 7th Infantry Division under the command of Lieut.-General von Fransecky. At half-past twelve on the night 2nd-3rd July, the regiment commenced its march to Cerekwitz from Horitz, and.between 8 and 9 a.m. the division advanced through Benatek against the Maslowed Wood which lies some $6-700$ paces south of this village.

The Wood of Maslowed, or the Swip Wald, was not marked on the maps, so that at the outset no one knew anything about its size or what the interior was like. It is irregular in shape, and it measures some 2,000 paces from east to west, and 1,000 paces from north to south. It covers the crest and both slopes of a ridge running from Maslowed to the Bistritz. The ridge culminates at two points of almost the same height, the western lying nearly in the centre of the wood, whilst the eastern is only partially covered with growth. From the latter runs out away to the west along the south of the-wood a deep valley which separates the ridge from another, on the' south slope of which is the village of Cistowes.

\footnotetext{
${ }^{1}$ By "regular" is here meant an officer on the peace active list of the Standing Army,-L. A. H.
} 
The Maslowed ridge falls steeply on the north side to the Benatek meadows.

The wood is divided into several sections by the road from Benatek to Cistowes, by one leading westward from Maslowed, and also by a glade extending from north-east to south-west. The wood lying to the west of this glade consisted of high timber trees, mostly fir and oak, both with and without underwood. East of the glade are young copses, bushes, and oak nursery plantations; only the particular patches which lie in a north-easterly direction outside the wood itself consist of timber. In the wood close to the east of the glade were many stacks of cut wood. They were often only a few paces apart, and they offered the same obstacles to progress as did in other places the thick undergrowth and the steep slopes. The edge of the wood on the south and east sides was in no way clearly defined. Many rows of fruit trees were on the ground in front leading to the open country, and these impeded the effective fire from the wood. Finally, it may be mentioned, that in front of the northeast re-entering angle of the wood, at a distance of 300 paces, there was a height which seriously interfered with the view in the direction of Horenowes.

It is necessary to bear in mind, as regards the fighting, that the Prussians carried the needle-gun, the Austrians the muzzle-loader. Of the four regiments forming the division, the 27th, and the Fusilier Battalion of the 67 th, were the advanced guard, the 66 th and 26 th were the main body, the 1st and 2nd Battalions of the 67 th were the reserve. The advance from Benatek against the north side of the wood commenced about half-past cight o'clock. This part of the wood was occupied by detachments of the Austrian Brigades, Brandenstein of the 4 th, and Appiano of the 3rd Corps. They did not, however, offer any resistance, but fell back, for the most part, in the direction of Cistowes. The northernmost parcel of wood, protruding towards Benatek, was held by the Austrians in force. The Fusilicr Battalions of the 27 th and 67 th had been leading the advanced guard on Benatek. The Fusiliers of the 27th were now directed against the western portion of the wood, and the other two battalions of the regiment followed them. The Fusiliers of the 67 th went against the projecting north-cast angle, thus disposing of the advanced guard, and they were speedily supported from the main body by the 1st and Fusilier Battalions of the 60th. Owing to the ex-centric advance of the 27 th to the west, and of the Fusiliers 67 th to the east, the centre of the wood remained in the hands of the Austrians. The advance of the two battalions of the 66th did not close the gap between the Fusiliers 67 th, and the 27 th Regiment; the Austrians held not only a part of the south edge, but also different points in the interior of the wood, so that, now and then, isolated detachments which had been cut off appeared as a surprise on the flanks and in rear of the Prussian companies and zugs engaged in the fight. Some 96 Austrian gruns from the directions of Maslowed, Chlum; and Lipa, concentrated their fire on the wood. It was into the gap in the fighting line, the centre of the wood, that about 9 o'clock the 26th Regiment moved forward. Owing 
to the order of march in which the three battalions of the regiment stood in the column, the attack was led by the Fusiliers. This battalion advanced in three lines, an extended zug of each of the 10th and 12th companies as skirmishers, followed by the two zugs of each of these companies in close order, with the 9 th and 11 th Companies in third line. The advance was exposed to rifle fire from the edge of the wood, and to the artillery firc already mentioned; one shell falling in the 6th Company killed five men and wounded seven; eight were knocked over by the bursting of one shell in the 8th Company. The staff-officers and adjutants remained mounted; the captains went on foot. The ground was very rough and torn by the shells, and was so heavy, owing to the rain, that it tore the boots off the feet of many of the men. A fusilier of the 10th Company went through the fight bare-foot. The two musketeer battalions (1st and 2nd) followed in the formation known as "Kolonne nach der Mitte" (column on the centre), with colours fyying and drums beaten. This formation is that of a close column of four companies each - in company column, two such columns deep, and two wide.

From the point $(a)$ was directed on the advancing Prussians a lively rifle fire. The strength of the enemy being unknown, the shooting-line was reinforced by a sccond zug from each company, the four zugs being led by Captain von Boltenstern of the 12th Company; but it was not until this line had come to 200 paces from the wood that it opened fire on the enemy. The hostile fire seeming to lessen, the commander of the 12th Company ordered the assault; the enemy, who was in small force only, did not await the bayonet attack, but at once retired in the direction of Maslowed, followed by the two Prussian companies, which now, in consequence of the close character of the wood, called up their remaining.zugs into the shooting-line. The Austrians retired very gradually, fronting from time to time at points favourable for defence; and, consequently, personal hand-to-hand encounters ensued: The eastern edge facing Maslowed was, however, gained, whence fire was at once opened on the enemy posted beyond; a very energetic counter-stroke by two hostile battalions in column failed before the defensive power of the needle-gun. The other two companies of the battalion, 9 th and 11 th, under the battalion commander, had followed the leading companies into and through the wood. There ensued now in the fight a short pause, which the major utilised to arrange the defence of the edge. The schützen zugs of the 9 th, 11th, and 12th Companies occupied the edge, the two other zugs of the companies being in support; the 10th Company was collected, and was stationed as a second line in rear of the right.

The major-general commanding the brigade had already lost his staff officer, whose place was now taken by the regimental adjutant of the 26th. To fill the vacancy thus created, the regimental commander took the adjutant of the Fusilier Battalion, so the commander of this battalion was without a staff officer during the remainder of the operations.

Following the Fusiliers, the 2nd Battalion, in column on the centre, had gained the northern edge of the wood, not, however, without loss. The brigade commander, who was with it, hearing the heavy firing of the 
10th and 12th Companies to the left front, and believing the enemy to be in force in that direction, ordered the battalion, still in column, to wheel to the left towards Maslowed. Although, in the thick bushes and undergrowth, the advance of so large a body in close order met with great difficulties, and halts were frequently necessary to restore order in all the zugs, Major von Gilsa, the battalion commander, considered that so long as an advance in this manner was possible, he must abstain from a deployment into company columns. When the battalion arrived at the further edge on the right of the Fusilier Battalion the two leading zugs were at once extended, and the deployment into one line took place, a gap between the battalions being filled by the schützen zug of the 8th Company. On the right of the line Captain von Ploetz had, with some of the 5th Company, occupied an angle (c) salient towards the south-cast, so that a portion of his shooters fronted east towards Maslowed and another portion south towards Lipa, whilst the support stood some hundred paces in rear.

The 1st Battalion was the last to enter the wood, and did so at the re-entering angle. The formation was in two lines of half-battalions. It first passed over on the Maslowed road, a strong abattis, behind which numerous dead Austrians showed the tenacity of the previous defence at that point. The further advance into the wood was here as difficult as had been that of the other battalions. The obstacles to progress consisted of thick. undergrowth, through which, here and there, a path had to be cut with billhooks, steep slopes with slippery surfaces, here and there big branches, or even whole trees, which had been cut down by the artillery fire. Delay in advance was but insignificant, however, for, with all the strength of lungs and muscles, everyone pressed forward. No one remained behind, all pushed onwards towards the enemy, and with exemplary rapidity order was restored in the companies and the zugs when it had been lost through the difficulties of the ground or the shells falling among the men. The 1st Company, which was on the right of the second half-battalion, had, unlike the three others, not passed over the abattis, but had passed round it to the west, and thus became the advanced guard of the battalion. Its commander, Captain von Westernhagen II., had, at first, extended under Lieutenants von Schierstedt and von Sanden, only one-and-a-half zugs, which went forward in the general direction of the south through the thick undergrowth; but when they arrived in the vicinity of the high knoll in the middle of the wood, they were received by a heavy fire in flank, which was the more unexpected because they knew that the 27th Regiment, which was on their right, had mastered the south edge of the wood, and, therefore, they had not anticipated coming upon hostile detachments so far in rear of the first line.

Lieutenant von Schierstedt, who was on the right of the line, immediately made the men nearest to him wheel round towards this unexpected attack, and open rapid firing, though only the heads of the Austrians were visible. Protected by this fire, the whole line wheeled to the right, and from the still closed half of the company the captain sent the 
zug of First Lieutenant Schulenburg direct against the enemy's position. The commander, by a bugler, communicated to the zug leaders his intention to make a concentric attack without delay, so that the whole line tolerably simultaneously, with " March, March, Hurrah!" advanced against the knoll. This was held by some 200 infantry and rifles of Appiano's and Brandenstein's brigades; in disorder, and apparently acting not under any one command, they were in no condition to repel the attack, but they retired in a south-westerly direction, where they were, for the most part, taken prisoners by the closed detachments of the 27 th Regiment.

South-east of the knoll, the Austrians held strongly a saddle, covered with low, but very close brushwood. The 2 nd and 4 th Companies were led against the enemy by the battalion commander, who had hitherto remained mounted, and whose horse was here shot under him. The enemy belonged to the 12th Regiment in the first line of Brandenstein's Brigade, which had repeatedly endeavoured to drive the Prussian advanced guard out of the wood, and which, at places, had been able to penetrate into the interior of the wood, owing to the further edge not being simultaneously occupied by the Prussians. After a short fire-fight the 2nd and 4th Companies advanced to the attack, and a stubbornly contested handto-hand fight ensued, resulting in forcing back the Austrians, and in the capture of a large number of them. The 3rd Company had followed the 1st to the knoll, on which the Austrian guns were pouring a hot shell-fire, Captain von Westernhagen being put hors de combat.

The 2nd and 4 th now advanced to the southern cdge of the wood, the 3 rd following as second line by order of the battalion commander, who directed the 1st Company to remain at the knoll. The 1st Battalion now occupicd the southern edge of the wood $(b b)$ to the right of the 2nd Battalion. It was now 9.30 when the regiment had gained the further edge. Now will be depicted the situation in which the regiment found itself.

As already mentioned, nearly 100 guns had for some time been playing from Naslowed and Chlum on the wood; and here and there fresh batteries came into action. As at Münchengrätz, the Austrians had carefully prepared the battle-field: on the tree tops were fastened crosses and other marks, which, not visible in the interior of the wood, could be so clearly discerned from the artillery position that hardly a shot fell short. Shells, shrapnel, and rockets followed each other in unbroken succession, at so short intervals, that it was difficult to detect single shots, and rather it seemed as if the enemy were endeavouring to drive out the 7 th Division by a series of salvoes of artillery. It was, in the fullest sense of the words, an iron shower with which the Austrians sought to overwhelm the wooda hell-fire, whose annihilating power was heightened by the splinters, boughs, and branches which the shells tore off and were hurled about, Large trees wcre broken like stalks of straw, and they crushed, in falling, men who had sought shelter behind them; and the yard-long logs in the numerous stacks of wood whirled about in the air like children's little wands. The detonations of the bursting shells, the hissing of the rockets, and the whistling of the bullets, with the crashing of the splintered wood, 
combined to form a hellish noise, in which the loudest command was audible only in the immediate neighbourhood, and any lower tone of voice was of no avail. The incessant rain kept the smoke of the powder low, and, at times, the smoke remained as a dense cloud before the fireline, and was as inconvenient to friends as to foes. It was frequently difficult, where in the wood the foliage was thick, to see beyond a distance of twenty paces; only with the greatest care could, therefore, connection between the different units be maintained, or, when lost, regained; among the high timber the darkness, among the low timber the more or less impenetrability of the undergrowth, hindered keeping the true direction, and even patrols could hardly succeed in getting from one company to another.

The view towards the enemy's side was, at the wood edge, very limited, so that after the higher leaders, generals, and regimental commanders had once issued orders for their battalions, it was almost impossible to regulate further action. The same state of things existed with the battalion and company commanders, who, only in rare cases, could work their whole commands for a single object; only here and there could the zug commanders keep in hand the fire of their collected groups.

- The; so to speak, dissolving character of wood fighting had even already made its influence felt, so that a real leading of the fighting ceased, and all leaders, high and low alike, were compelled to influence by their personal conduct the men in their immediate vicinity; whilst the men, out of sight or hearing of their leaders, were thrown on their own resources. The individual training of the soldier here bore its fruit; discipline and devotion to duty gained the highest triumphs; and here, also, was shown that the victory over the Austrians was not due to the needle-gun alone, but, in the first place, to the excellence of the soldiers who carried it. The losses in officers had already been heavy; in the 1st Battalion two officers and one Portepeefahnrich, in the 2nd one, and in the Fusilier Battalion six, including the Battalion Commander whose place was taken by Captain von Boltenstern. The desire for fighting was so keen among the men, that during the advance many of them had taken possession of the ammunition on their wounded comrades.

The Fusilier and 2nd Battalions had been engaged in a firefight at the eastern edge facing Maslowed, driving back vigorous and brave attacks by their fire, reserved in some cases until the Austrians had approached to within a hundred paces distance. The supports, as well as the shooting-line, of the Prussians suffered heavily from the hostile artillery ; the 5th Company, the right of the 2nd Battalion, losing nearly thirty men in the first quarter of an hour; other companies suffered not less.

As an illustration of the coolness of even the non-commissioned officers may be given the conduct of Sergeant Schaeffer, in collecting the support of the 5th Company. "Here am I standing in front, and no bullet has hit me," he said to the men, who after the burst of a shell had 
not immediately taken their places in the centre of the foremost zug. "Attention; right dress; number; advance arms"; and quietly, as if no enemy were to be seen far and wide, he went to the captain and reported, "The company is formed."

In connection with the fight at this part of the wood it may be mentioned that a certain private of the 8 th Company, Gothardt by name, the sole man of a group of shooters, not hors de combat, was opposed at short range by six Austrian Jägers, four of whom he disposed of by a single shot at each; and as the two survivors held their ground he went forward and bayonetted one, the sixth taking to his hecls. In reply to a question by an officer who has been watching him as to his success, "Only pretty good, Herr Lieutenant," he replied; "Four hits and a bull's-eyc" (vier Figuren und ein Centrum).

Emboldened by the repulse already mentioned of the Austrians towards Maslowed, the shooting-line of the $9 \mathrm{th}, 11 \mathrm{th}$, and 12 th Companies had, without any previous concert, burst almost simultaneously from the edge of the wood, determined to follow up their success; the supports followed, and by order of Captain von Boltenstern who, as already mentioned, had succeeded the wounded battalion commander in the command, the 10th Company followed in second line. In the face of the overwhelming fire which the battalion had to encounter, the attack could not possibly succeed, and in the retirement to the edge of the wood, the losses cxceeded those suffered in the advance. Meantime, detachments of the 66th Regiment had reached the edge of the wood and received the Fusilicrs, the supports of which now halted, fronted, extended, and entered the shooting-line of the 66th; the shooting-line became one in which men of different regiments and companies were mixed up; tactical units ceased to exist, and the officers collected together those men who were nearest to them, and within sound of their voices. From Maslowed the Austrians followed close on the heels of the retiring Prussians; owing to the very heavy rain at this moment, the advance at some points was not seen in time; moreover the Prussians could not open fire until all their comrades were back again in the wood. The entry into the wood by the Austrians could not therefore be prevented, and it was only after a hand-to-hand combat that they were driven out, and the edge of the wood regained. Three officers and nearly 100 men was the cost of this premature but daring attempt to profit by the original defeat of the attacking Austrians. But the fight did not end here, for to receive the Austrians driven out, there advanced from Maslowed a Jäger Battalion. Major von Gilsa of the 2nd Battalion observing this, ordered Lieutenant von Bismarch to move out the support of

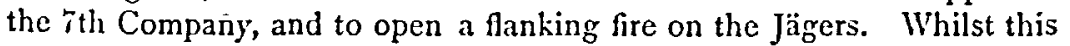
movement was being carried out, the battalion adjutant ordered out the supports of the 6 th and 8 th Companies, which took post on the right of that of the 7 th. With these went here and there men from the shooting line. This portion of the 2 nd Battalion advanced towards the north, and after driving back the Jägers and crossing over the hill had now to fall back to the edge of the wood, and was for the remainder of the fight 
separated from the sth Company, and the scattered portions of the battalion which remained in their original positions. The battalion commander had fallen in this fight. Subsequently the commander of the 6th Company, seeing two Austrian companies apparently isolated from their regiment issued from the wood with the 6 th and 7 th Companies and routed them. Captain von Boltenstein of the Fusilier Battalion, finding his fire masked by the 2nd Battalion, ordered his company commanders to withdraw their men from the edge of the wood, and to re-organise them further in rear. The units thus formed consisted of men of all four companies, time not allowing further redistribution. At this part of the wood had already commenced the mixing up of regiments, battalions, and companies.

To return to the 1st Battalion. Against the southern edge the Austrians had already advanced from the direction of Cistowes before the arrival of the 2 nd and 4 th Companies. The Austrian 13 th Jägers had entered the wood, and moving in a north-westerly direction passed by the right flank of these companies and eventually encountered the 1st Company, which had been left at the western knoll on the ridge. Against the 2nd and 4th Companies, which had barely time to place their shooters in position at the edge and to bring up the supports into the firing-line, the battalions of an Austrian regiment, supported by the flanking case fire of a baltery advanced. The first attack beaten off, the 3rd Company was brought up into the line and the renewed attack repulsed, some of the 27 th Regiment on the right taking part in the defence. Meanwhile from the 1st Company on the knoll several patrols had been sent out to the south and west to keep up communication with the rest of the battalion and to ascertain the state of affairs in the western part of the wood. Those sent to the west came quite suddenly in the dense undergrowth on the advancing 13th Jägers, and must all have been killed or taken prisoners, for the first intimation of the attack was the sudden opening on the right flank of this company of a heavy fire, before which the surprised groups at once abandoned their position and fell back. The company now retired, being pursued by fire only, which ceased as soon as the Prussians disappeared from view in the wood. Rallied by the energetic efforts of the officers and the non-commissioned officers, the retreating shooting-line was brought to a stand on a level with the supports about 100 paces in rear. A few minutes later, the whole company, two zugs extended, and the third closed in the centre advanced to the atlack. 'The Austrians were in their turn completely surprised; they fired unsteadily and too high; their front line falling back, came on their own advancing supports and hindered them firing, and in a few moments the whole Austrian line turned and fled westerly, leaving the Prussians in possession of the knoll. It was now about 10 o'clock, and a short pause arose in the fight, which was at 10.15 renewed by the attack from the south by the Austrian Poeckh Brigade; with this attack commenced the decisive struggle for the possession of the wood. The whole of the 7 th Division was in the fighting-line; of reserves there were none, whilst the Austrians repeatedly sent fresh intact brigades into the fight, supporting them by the fire of 128 guns. 
Up to this time the commanders had been able to keep the tactical units fairly together and to restore order during the pauses of the fight; but the fight which now commenced, and which was carried on for the most part in the interior of the wood, can be described only as a pell-mell of different battalions, companies, and zugs. The scattered troops, deprived of their leaders, losing their way in the dark and the powdersmoke, and attacked in overwhelming force, sometimes in front, sometimes in flank, rallied round the nearest officer, indifferent whether he was one of their own or not, and even round some non-commissioned officer or energetic private soldier, to be led again against the enemy.

The attack on the southern edge directed its right on the south-east angle of the wood, the left passing east of Cistowes and moving north. It was carried out by the Regiment Archduke Karl and the 8th Jägers. To meet this attack were the four weakened companies of the 1st Battalion, the 1st Company having been brought up from the knoll, and on each flank also detachments of the 2 th Regiment. On both flanks of the battalion the Austrians gained a footing in the wood, but meeting in the interior men of the 66th and 67 th Regiments they were driven out. The attack on the gith in the centre was repulsed. The unsuccessful attack was renewed by sis fresh Austrian battalions. It was impossible for the defenders to hold their ground against the brave and determined advance of this overwhelming force; the Prussian officers, hastening from one zug to another, encouraged their men by word and example, but gradually the 26th and 27 th fell back, holding tenaciously to every favourable clump of trees until turned in flank, or until over whelmed in front, when the retirement had to be continued. But when the knoll and the saddle, where the 1st I3attalion had first encointered the Austrians in the morning, was reached, it was possible to organise a defence, and then the tide began to turn; for whilst the Austrians were held in front, some companies of the oith advanced from the west against their left flank, and a company of the 66th, with the 9th and 10th Companies of the Fusilier Battalion of the 26 th, which had been got together after their fight on the eastern edge, attacked their right flank. The Austrians, their retreat thus endangered, fell back; the Prussians followed encrgetically, and again at 10.45 was the southern edge in the hands of the Prussians.

But now General von Fransecky, who on foot, owing to the loss of his horse, had come to the knoll and was nearly taken prisoner there by some of the Jiigers, received information that the reserve battalions-the 1st and 6 th th of the division-had already gone towards the south-west of the wood, and that the Austrians were developing an attack along the line Maslowed-Horenowes on his left rear. The general, therefore, directed Major Paucke to collect the 1st Battalion and to undertake the occupation of Benatek. Of the battalion, only the support of the 3rd Company, having not been under heavy fire, retained its tactical colesion; this was joined by two zugs newly formed of men of other companies; with these four zugs. and the section with the colours, Major Paucle movel. off about 11 o'clock towards Benatek. With the 
remainder, and with men of other regiments in the neighbourhood, Captains von Westernhagen I. and von Horn, commanders of the 2nd and 4th Companies 26th Regiment, proceeded to form two companies each of 100 to 150 men, and in two zugs. The zug leaders, who were two first lieutenants, one second lieutenant, and a portepcefahnrich, belonged to the 2nd, 1st, 4 th, and 3rd Companies, respectively. During the fight just described, the 5th Company of the 2nd Battalion retained hold of the projecting angle at the south-east point of the wood. The trees here were high, and stood up, against a clear background, so they formed a good target for the Austrian guns; and the loss of the company, some fifty men, was mainly due to the artillery fire. The frequent attacks by the Austrians never came nearer than 100 paces, and during them the Prussians enjoyed a respite from the fire of the artillery.

On the eastern edge facing Maslowed in two groups at the northeast and south-east angles $(d d)$ of the piece of wood standing out towards the village, the rest of the and Battalion, with companies of the 66th Regiment between the groups, held their own. General Fransecky had ordered the 9 th, 10 th, and 12 th Companies of the Fusiliers, who were originally here, to go to Benatek. 'The 9 th and 10 th received the order when occupied in rallying after their repulsing the right wing of Poeck's Brigade. The 11th and 12th only partially carried out the order; the greater part of them, under the battalion commander, Captain von Boltenstern, are found on the left of the 1st Battalion when this had regained the southern edge of the wood. Captain von Westernhagen had, after driving back some Jägers by his newly-formed company of the 1st Battalion, also arrived here with half of it; the other half not moving forward, as deceived by the thickness of the wood its commander did not understand the situation. Some of the 66th Regiment were here also.

The defending force at this part of the southern edge consisted, therefore, of the jth Company, half von Westernhagen's company, von Horn's company, von Boltenstern's half battalion of the Fusiliers, von IVerder's half battalion of the 60 th, and small bodies of the 27 th Regiment. Taken altogether they mustered little more than one Prussian battalion at war strength, and what with the march on the preceding night and the fighting in which they had already taken part, they were fairly exhausted. The attacking force now adiancing was fourfold their strength, and onehalf of the force had not yet been under fire. 'The front occupied by the defence was some 800 paces, and was, therefore, out of proportion to the numerical strength of the defenders. With the attack from the south came simultancously one from Maslowed against the eastern edge. The defence on the southern edge had now to give way, and fell back to the crest of the ridge in rear, where, aided by the 4 th Rifles and a battalion of the 72nd Regiment from another Prussian division, the frontal attack was held; von Boltenstern's half battalion of the Fusiliers being, however, forced to retire still further in a north-easterly direction to the eastern edge. Past the right flank of the Prussians bodies of Austrians forced their way, a battalion of the Eraherzog Karl Ferdinand Regiment arriving finally at the open ground beyond the north-west edge, were 
surprised by a squadron of the Prussian 10th Hussars; they were taken prisoners. ${ }^{1}$

The left flank of the force attacking almost simultaneously the eastern edge, sought to combine with the right of the south attacking force, and now the 5th Company at this exposed point had to give way. The company had lost nearly $100 \mathrm{men}$, about half its strength, and only $\mathrm{i} 0$ to 80 men could be collected for the retreat in a northerly direction. The main castern attack failed, however, owing to support received by the defenders from companies of the two alrealy named battalions of the 8th Division, and the attacking force was followed into the open. A third attack was, however, successful. The rood edge had to be given up. In the retreat every foot of ground was contested; but slowly fell back the Prussians, all tactical cohesion at an end, Musketeers, Fusiliers, the 66th Regiment, the 26th Regiment, companies and zugs, broken up and all forming a molley crowd, cach fighting as often under some officer strange to him as under his own. The right wing of the eastern attack was, pressing hard forward towards the northern edge, and here encountered von Boltenstern's half battalion already driven back from the southern edge and ridge. It no longer consisted only of men of the 11th and 12th Companies. A portion had disappeared, having lost tonch in the fight in the interior of the wood; on the other hand, men from other regiments and battalions had closed to it, so that all corps in the division were represented in it. $A$ s the encmy closed, a successful counter-attack resulting in the capture of numerous prisoners was made. For between three and four hours had the wood fight now lasted; noon had arrived, and by this time the regiment which at 9 had entered and then traversed the wood in perfect order, and had to the last used every endeavour to maintain that order, was now thoroughly broken up. The situation in each battalion was as follows:-

1st Battalion: The combined company of ron Horn, with a zug of that of ron Westernhagen, were fighting in the middle of the woorl; another zug of the latter company was struggling hard against the Austrian Jägers. In the north-east projecting piece of wood was another zug, which in the first advance had been detached in that direction to protect the flank. The headquarters of the battalion, with four newlyformed zugs, were occupying Benatek.

2nd Battalion: The 5th Company, reduced to half its strength, was the only company in any way resembling an original unit; it was retreating to the northorn edge, where it joined part of the 8th Company which had been driven back from the eastern edge. Some schützen

1 The capture of this battalion is recorded in the Prussian official account, where the statement is made that the battalion had lost all idea of its whereabouts. The incident has been frequently quoted as an instance of the difficulty of leading in woods. It seems, however, most improbable that a battalion going forward unopposed should have made such a blunder in traversing from south to north the Wood of Maslowed. The account given in the Regimental History of the 26th seems far more likely to be correct, and it is reasomable to doubt that the battalion lost its way at all, but that they were surprised by cavalry when issuing from the point at which they ainned.-L. A. H. 
groups of the 5th Company had joined the 6th Company which, with the 7 th, was still obstinately resisting the progress of the Austrians from the eastern side; the 6 th, 7 th, and 8 th Companies were so inextricably intermixed, that each contained hardly more than half its own men.

The Fusiliers, in much a similar condition, were either in Benatek or were fighting in the eastern part of the wood. From the northern edge had issued from time to time stragglers who had lost their way. These were at once organised into zugs by a staff officer, and re-entered into the fight. Detached bodies of Austrians, which had advanced past the Prussians in the wood, were now emerging from the northern edge from time to time, and even fruitlessly altempted to gain possession of Benatek.

The division itself was similarly split up: in the south-west angle fought principally the 27 th and 67 th Regiments. In the centre, parts of the 26th, a half battalion of the 66th, and portions of both battalions of the 8th Division. This force was completely isolated, and momentarily expected an outflanking attack both on the east and west. That this did not take place was due probably to the difficulties of sceing and leading being common to both the Austrians and the Prussians. In a wood, neither defeat nor victory is at once apparent, and, therefore, for a time the disasters due to the former, and the reaping of the fruits of the latter, are temporarily postponed. On the left wing partics of the 60 th and 67 th still held the smaller pieces of wood, and small detachments, nearly all in extended order, sought to hem in the Austrians who had already penetrated into the eastern edge, and to thus stop their further advance. Fousteen battalions and 24 guns had fought against 128 guns and more than 50 battalions for the possession of the junction point of the 1 st and 3nd Prussian Armies.

Soon afterwards arrived on the left the Guards Corps of the Crown Prince's Army; the Austrians gradually retired, the task of the 26th Regiment was completed, and the wood fight was over.

The losses in each company were as follows:-

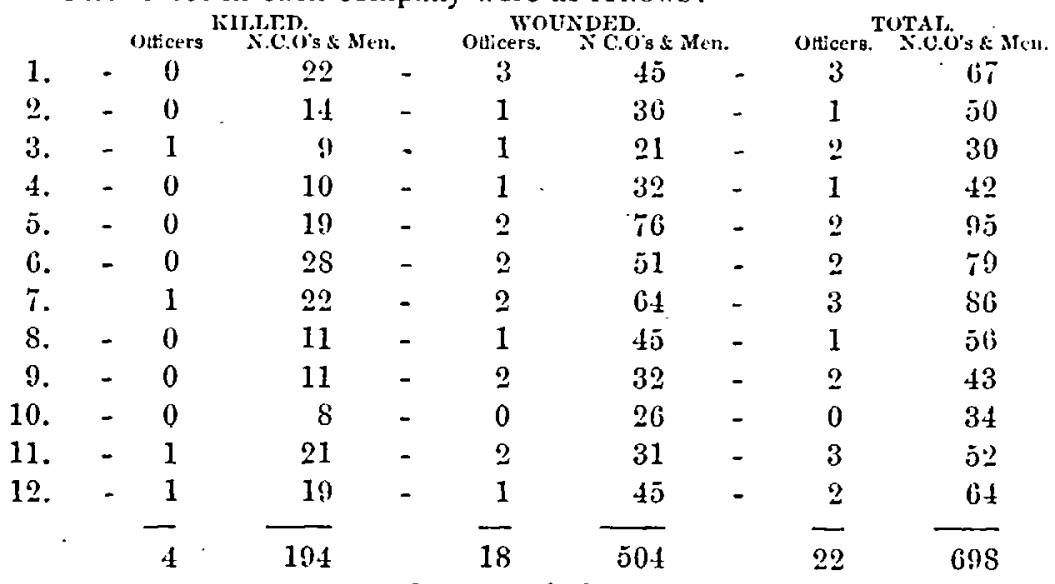

8 men missing. 
In addition to the above, one battalion commander was killed; one battalion commander, the regimental adjutant, and a battalion adjutant wounded.

\section{REMARKS.}

The leading of the 26th Regiment in the Swip Wald scems to me to be a model for that leading which is required for modern war; but I have been somewhat doubtful whether it is wise to publish it in a journal widely circulated in our Army, for neither in barracks nor out in the field are the units of that Army, large or small, yet emancipated from the heary yoke of centralisation of command and responsibility; and in the foregoing narrative, and also in that which follows, the enemies to decentralisation may find facts supporting the pernicious doctrines they maintain. My own view is that if centralisation needs diminishing, decentralisation needs control, and I regard the Swip Vrald as an illustrative instance of centralisation properly exercised; whilst the succeeding narrative will show the evils of decentralisation uncontrolled.

The two chief characteristics of the operation just described are, first, the firm hold retained for so long by the battalion and company: officers over their commands; secondly, the consequent postponement of the arrival of that period of confusion and chaos which must eventually prevail to a greater or less degree in every stubbornly contested fight for the possession of woods, and, in fact, in all hard fighting. It will have been noticed that practically the whole regiment, notwithstanding occasional encounters with the enemy, and in spite of the physical difficulties in the path of the advance, arrived at the southern and eastern edges of the wood in as orderly formation as if they had been advancing from one end of an open plain to the other. Less the haste more the speed, was strikingly illustrated here. But those were the days before the company leader assumed the position of an irresponsible autocrat. The companies regarded the battalion as the body of which they severally were the members. Unnecessary precipitancy in the devolution of control was at present unknown. Absolutely necessary as is this devolution in modern war, the right judgment of the moment when it becomes necessary is one of the marks of the real leader of every tactical unit great or small in the present and the future; and the Swip IVald also shows, "Get into order" must be the call by every tactical leader in the pauses of a fight, and "Rally to me" that of every such leader when in the stress of battle his men are being swept back by an on-rushing and hostile tide.-L. A. H.

\section{The Advance through the Bois de Givodeau, 30ril Augusi, 1870. (Plan II.)}

In striking contrast to the leading just described was that of this same regiment in 1870 . Four years later, the 26th Regiment finds itself ordered to advance against the southern edge of the Bois de Givodeau. In the personnel of the officers, the regiment has greatly changed during that short period, owing, to a great extent, to the drafts on it to furnish contingents of officers and non-commissioned officers for the formation 
of new regiments. There is a new regimental commander from another regiment; similarly a new commander of the 2nd Battalion. Major Fritsch, who led the 6th Company at the Swip Wald, now commands the 1st Battalion; the former commander of the Fusilier Battalion has only four lays ago been sent to command another regiment, and has been replaced by Captain von Lucadou, who was with the Ersatz Battalion in July, 1860. Only the 2nd, 4th, and 7 th Companies have with them their old chiefs; four other companies are led by officers who were present in the Swip IVald ; the remaining five company leaders were not there. Fight officers of lower rank who were in that fight are still with the regiment, three of the adjutants the same; so that altogether nineteen out of the sixtyeight officers with the regiment had had experience of leading in woods: Among the subalterns were no less than four portepeefähnich, twelve second lieutenants of the Làndwchr, and fifteen regular vice-sergeantmajors. Of the sixty company officers, twenty-nine were on its active list in peace-time. On mobilisation five companies had passed into the hands of new commanders. The regiment is in its old brigade the $13 \mathrm{th}$, with the 66 th Regiment as before.

At about 3.30 p.m. the 13th Brigade, which, as in 1866, was composed of the 26th and 60th Reriments, was on the east side of Beaumont, having advanced from the south, driving back the French, who, overwhelmed by the powerful artillery fire of the Germans, had withdrawn their guns from the ridge on which stands the Bois le Fay, and with their infantry also had disappeared northward under cover of the Bois de Givodeau. The brigade now moved towards the wood, the 26 th being in second line to the sister regiment-the 66th. Owing to the brigadier having been wounded, and Colonel von Schmeling having to take his place, the command of the regiment had devolved on Major Fritsch, who was replaced by Captain von Horn. In the further advance the 66 th Regiment was directed against the south-west angle of the wood, the 26 th against the southern edge and the southeastern angle. Only one company had opened fire against the rood, from the edge of which the French were plying their chassepots; the edge was taken by a sort of spontaneous rush, and along the edge the regiment rallied in the following order of companies from right to left :11 th, 12th, 9th, 3rd, 4th, 1st, 2nd, 8th, 7th, 6th, 5th; the 11th had extended two zugs, the other companies only one. The 10th Company was absent on baggage-guard duty. By order of Major Fritsch the extended zugs and the supports halted at the edge to restore the order lost in the attack. It was now 4.30 p.m. The advance was now to be continued. Major Fritsch, therefore ordered that to traverse the rood all companies should go forward in a northerly direction from their present position ; and he further directed that, on arriving at the further edge, they should await orders. It is well to note that the officers of the German Army did not make use of the magnetic compass in this campaign. The Bois de Givodeau is about 1,500 paces deep from south to north, and 2,300 paces wide from east to west. Its character is described in the History of the Regiment as follows. 
The wood is strikingly sinilar to the Swip Wald on the battle-ficld of Königgrätz. Both woods are of about the same size, and also irregular in shape, but the saliency of the Bois de Givodeau on its southern side is far more pronounced. Both are on hills, the sides of which are cut into by numerous lateral valleys, and are of many varying degrees of slope. The passage through the eastern portion of the wood is much more difficult than that of the other parts, and is hardly practicable for infantry, for the hill falls tolerably steep to the Neuse, and in some places is almost precipitous. Unlike the Swip Wald, the Bois de Givodeau consists almost entirely of high leafy trees. Here and there there is thick undergrowth, which consists partly of briars forming thickets, to be broken through only with an expenditure of time and labour. The ground was slippery from the rain, and in the interior of the wood a sort of twilight prevailed.

On the plan (Plan II.) is shown the relative positions of the companies and zugs on their arrival at the further edge. The positions are reproduced as given in the plan in the Regimental History. To that plan is appended a note to the effect that for the better understanding the situation the schiitzen zugs which separated from their companies are shown as closed bodies.

The course taken by each company in traversing the wood will now be described beginning with the right of the original line the 11th Company. This company had, for the attack on the south-eastern point extended two zugs, the right zug being under Licutenant Fulda, who had received the order to extend to the river Meuse, and to advance north along the bank of the river. The subsequent order given by the regimental commander to halt did not reach him, the bearer having been killed on the way by a chassepot bullet coming apparently from beyond the river. $\Lambda$ s soon as Lieutenant Fulda had entered the wood the half of the other zug joined on to his own zug, and he arrived in due course with one-and-a-half zugs at the northern edge where he halted and awaited the arrival of the remainder of the company, which he believed to be following close behind him. Captain von Collas, the company commander, had of course intended to follow Lieutenant Fulda, but owing to the closeness of the southern part of the wood failed to maintain the true direction. In the endeavour to force their way through underwood and thick brambles, the closed zugs got so far apart that Major Fritsch ordered Portepeefähnrich Witte to extend half a zug to cut a way with hatchets and side-arms. The men worked hard, but were far too slow for the impatient company leaders. Gradually the wood became more open.

Some sixty or seventy prisoners were captured by Portepeefähnrich Witte in the bushcs. Through bushes and brambles, and frequently obliged to go round them, the one-and-a-half zugs gradually lost direction more and more, and when they eventually reached the open they found themselves at the north-western edge instead of the north-eastern. and some 2,500 paces away from the other half of the company.

12th Company-This company, with which the battalion commander went, had extended one zug in advancing against the wood. The company moved forward on the left of the 11th Company, but soon lost 
direction, inclined to the right, presumably in rear of the 11 th. After some time it struck on the road along the bank of the river, and emerged from the wood at the north-castern edge, where it joined the half of the 11 th Company under Licutenant Fulda.

9th Company-In close proximity to the above, and at the extreme eastern end of the line, came the two zugs, the support of the 9th Company under Second Lieutenant Holtzheuer. The schuitzen zug of the company, under the company commancler, had first entered the wood, and then diverging more to the west had got separated from the support, which went more to the east. The two groups were some 500 paces apart. The company had been somewhat in advance of the others when moving against the southern edge.

4th Company-The extended zug under Lieutenant von Sanden had led into the wood. On the right of this zug came the single extended zugs of the 3rd, 1st, and 2nd Companies between it and the 12th Company. This company, as already mentioned, had edged away to the east to the river road. In order to maintain connection, these three zugs of the 1st Battalion did the same. Whilst moving in this direction they were met by the battalion adjutant, who brought them back again to a northerly direction, and eventually they arrived at the edge on both sides of the Sartelle-Villemontry road. Lieutenant von Sanden, with the extended zug of the 4th Company, was not aware of this original edging away to the east until he had lost touch with the other zugs. So soon as he learnt what had happened he moved also eastward to regain touch. But, as just mentioned, the zugs had again changed direction to the north. Lieutenant von Sanden must have, therefore, passed in rear of them, and on reaching the edge of the wood he found himself in the river valley. The two supporting zugs of the company maintained direction, and issued west of the Villemontry road.

3rd Company-The supporting zugs of this company and the schützen zug collected also close to the same road.

2nd Company-The position of the schützen zug has already been given. The two supporting zugs struck on the left half of the 11 th Company in its erratic course to the north-hest, followed it, and eventually arrived on the north-western edge on the Mouzon road some 1,800 paces in a direct line away from its other zug.

1st Company-This company emulated the 2nd in its divergence from the correct direction, and is found with its supporting zugs on the extreme left of the line yet further distant from its schützen zug than were those of the 2nd Company.

8 th and $T$ th Companies-To these two companies, accompanied by the battalion commander, it fell to have to pass through a specially difficult part of the wood. Only by twos and threes could progress sometimes be made, and the advance was slow. Fortunately, the original direction was maintained, and they arrived at the right point, having lost only one of the extended zugs-that of the 8th Company-which, having been engaged in capturing French soldiers found in the wood, had gradually, gone in a more'westerly direction, and a thousand paces 
distance, found itself the right zug of the medley of zurs facing northwest on the Mouzon road.

6th Company-Into the line just mentioned had entered together the schützen and supporting zugs of the company, which had kept together but had lost direction.

5th Company-Between the 6th Company and the schiitzen zug of the 8th came now the supporting zugs of the 5th Company, the schiitzen zug having gone north about 1,200 paces away. The commander of the company had been placed hors de combat before entering the wood, and the leading had devolved on a second lieutenant of the Landwehr from the 6th Company. In the wood the commander of the schützen zug, a second lieutenant of the Landwehr, was wounded, and was replaced in command by a vice-sergeant-major doing duty as an officer.

Although the French offered no resistance in the wood, shots. were constantly heard and on all sides.

At about 5 p.m. the positions shown in the sketch had been reached. The leading in the wood had broken down completely, and the regiment found itself in two widely separated groups; the eastern group of a strength of about seven companies, of which two only were intact; the western group of a strength of four companies, only one company being intact. With the former was Major von Rostken, the commander of the 2nd Battalion, Captain von Horn, the commander of the 1st Battalion, and Captain von Lucadou, the commander of the Fusilier Battalion; with the latter the regimental commander, Najor Fritsch. Unity of command was now out of the question, so far as the regiment was concerned. Rallying took place where possible. Portions of the western group became involved at once in a struggle against the enemy; and ITajor Fritsch, who still retained hold of about three companies, on finding the 93rd Regiment, in the sister brigade, advancing northward on his left, joined with them in the advance, and directed the regimental adjutant to direct all detachments he could find in this part of the wood to collect at a quarry to the north. Eventually a miscellaneous group of twelve zugs, numbering in all some 700 men, assembled at the quarry. Among them was the whole of the 6th Company. From the rest was formed two half battalions. The first consisted of two zugs of the 1st and two zugs of the sth Company, the command being given to Second Licutenant Gräser, an officer from the Reserve; the second was made up of two zugs of the 2nd Company, one of the 8th, and one-and-a-half of the 11th, the command being given to Captain von Collas, the leader of the 11th Company. As a unit, the regiment had, by its unorderly advance through the wood, become useless for any further operations against the enemy who were holding the ground beyond.

\section{REMARKS.}

One of the most remarkable points in this operation is that the order to advance in line from the southern to the further edge in a northerly direction emanated from the officer, Najor Fritsch, who in the Swip Wald commanded a company in the battalion of which the com- 
mander, Major ron Gilsa, as already narrated, considered that so long as an advance in a close battalion column was possible, it was desirable to delay the deployment into company columns. The explanation of the unsatisfactory conduct of the operation of 1870 as compared with that of 1866 lies, I entertain not a shadow of a doubt, in the desire for independent leading, which was fostered so strongly in the intervening period by the change from close to morc open tactics. Corroborative proof of the explanation is forthcoming for those who study the working of battalions in the war of $1870-1$; but there can be few soldicrs who will not prefer the leading of Major von Gilsa to that of Major Fritsch. A burning desire to get at an enemy is a highly laudable fecling, and ought in every way to be encouraged; but, if in the advance, or when hurrying to the "sound of the guns," the unit loses the main portion of its fighting power as a unit, indulgence of the feeling leads it on the high-road to disaster.-L. A. H. 

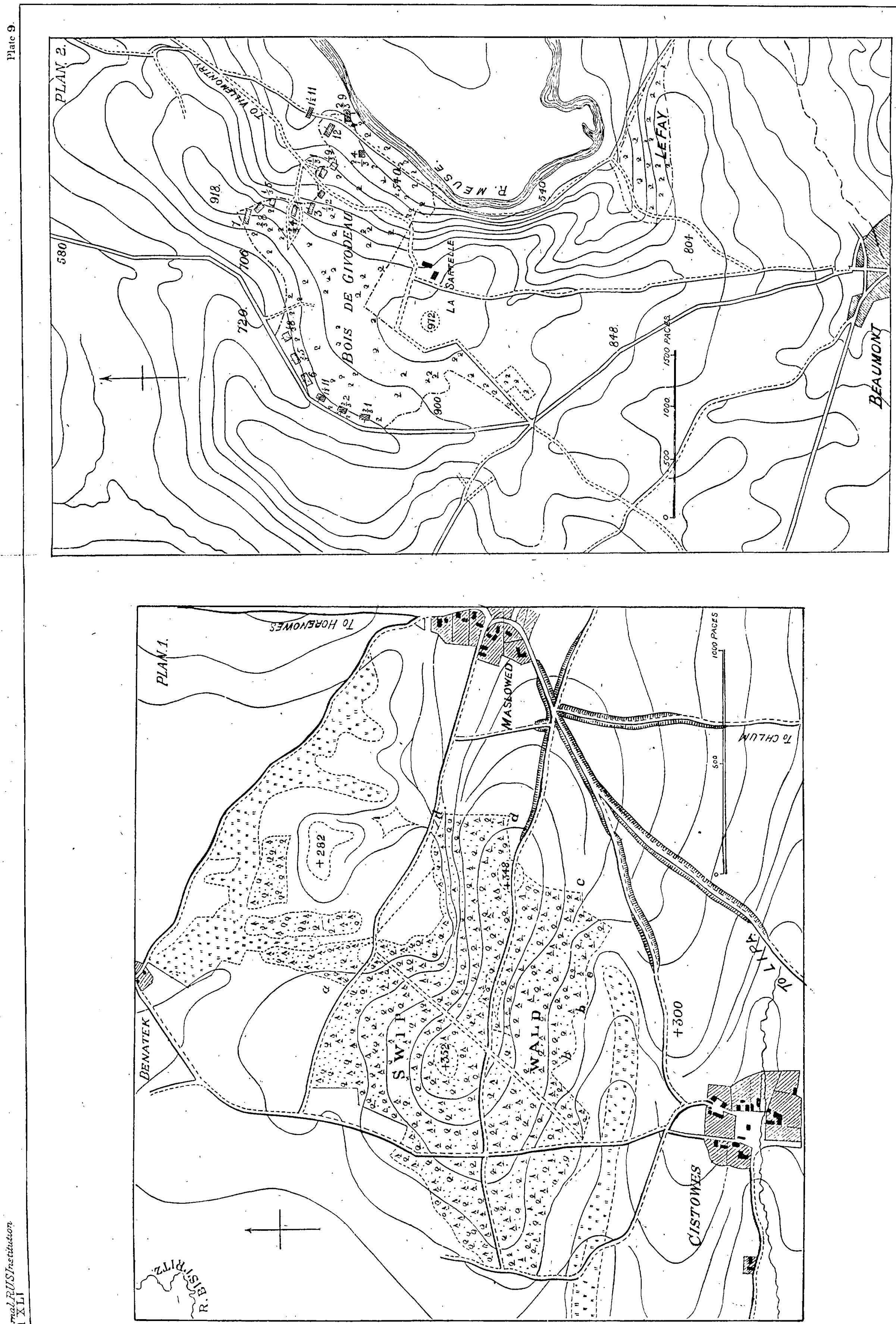